\title{
Cardosins A and B, two new enzymes available for peptide synthesis
}

\author{
Ana Cristina Sarmento ${ }^{a}$, Liliana Silvestre ${ }^{a}$, Marlene Barros ${ }^{\text {a, } *}$, Euclides Pires ${ }^{b}$ \\ ${ }^{\mathrm{a}}$ University of Aveiro, Dept. of Biology, 3810 Aveiro, Portugal \\ ${ }^{\mathrm{b}}$ University of Coimbra, Dept. of Biochemistry, Ap. 3126, 3000 Coimbra, Portugal
}

Received 25 November 1997; accepted 2 December 1997

\begin{abstract}
Two new aspartic proteases, Cardosins A and B, with a high specificity toward bonds between hydrophobic amino acids were isolated from the flowers of the cardoon, Cynara cardunculus L., and recently characterised [C.J. Faro, A.G.J. Moir, E. Pires, Biotech. Lett., 14 (1992) 841.]; [P. Veríssimo, C. Faro, A.J.G. Moir, Y. Lin, J. Tang, E. Pires, Eur. J. Biochem., 235 (1996) 762.]. Cardosins were shown to be stable in aqueous-organic biphasic systems [M. Barros, M.G.V. Carvalho, F.A. Garcia, E. Pires, Biotech. Lett. 14 (1992) 174.]. In this work, we have investigated peptide bond specificity of Cardosin A and Cardosin $\mathrm{B}$ in what concerns the amino acids in $\mathrm{P}^{\prime} 1$ position. The results were compared with pepsin under the same conditions. Information about secondary specificity of Cardosin A and B was also investigated by tripeptide synthesis. The condensation reactions were carried out in aqueous-organic biphasic systems of $n$-hexane/ethyl acetate and sodium phosphate buffer. The reaction products were isolated by RP-HPLC and identified by amino acid analysis and eventually by M.S. The results in the synthesis of dipeptides showed that Cardosin A and B have similar $\mathrm{P}^{\prime} 1$ position preference. The production of tripeptides by condensation of $\mathrm{CBZ} \cdot \mathrm{Val} \cdot \mathrm{Phe}$ with $\mathrm{Phe} \cdot \mathrm{OMe}$, Met $\cdot \mathrm{OMe}$ and $\mathrm{Val} \cdot \mathrm{OMe}$ reveals that the addition of Val in the P2 position modifies the Cardosins' preferences concerning the amino acid in $\mathrm{P}^{\prime} 1$ position. (C) 1998 Elsevier Science B.V. All rights reserved.
\end{abstract}

Keywords: Aspartic proteases; Specificity; Organic solvents

\section{Introduction}

In the growing field of preparative synthesis of peptides, enzymatic peptide synthesis has become an integrated part of the synthesis, valuable as a synthesis technique per se and as a tool for fragment condensation [1]. Enzymatic synthesis can usually proceed very specifically [2], without racemization and protection of reac-

\footnotetext{
*Corresponding author. E-mail: mbarros@bio.ua.pt
}

tant's side chains. Thus, a central aspect in the development of this technology is the search for enzymes with a very well defined specificity. The two main advantages of enzymatic peptide synthesis are the high specificity of the reaction and the absence of any side chain protection requisite.

The major focus for synthetic process development has been dipeptide products. The reason for these developments has been the increasing importance of dipeptides in human areas for nutrition, flavouring and medical purposes or in 
agrochemistry for animal nutrition or as pesticides [1]. There is a great interest in enzymes able to perform peptide bonds like Phe-Val, Phe-Met and Phe-Phe for production of biological active peptides such as enkephalin, dynorphin and substance $\mathrm{K}$ and their analogues.

The isolation, purification and characterisation of two aspartic proteinases, Cardosins A and $\mathrm{B}$, have been described in our lab by Veríssimo et al. [3] from Cynara cardunculus L., a cardoon traditionally used for milk clotting in the manufacturing of cheese. Cardosins exhibit a high preference for bonds between hydrophobic amino acids [4]. In addition, Barros and co-workers $[5,8]$ have shown that these enzymes are very stable in aqueous-organic biphasic systems and more effective than pepsin to perform the synthesis of the dipeptide derivative $\mathrm{CBZ} \cdot \mathrm{Phe}-\mathrm{Met} \cdot \mathrm{OMe}$ in these systems.

\section{Materials and methods}

\subsection{Materials}

Cardosins A and B were purified from dried stigma of $C$. cardunculus L. by a two step procedure involving extraction at low $\mathrm{pH}$, gel filtration and ion-exchange chromatography, performed as previously described, with slight modifications [3]. CBZ $\cdot$ Phe, $\mathrm{CBZ} \cdot \mathrm{Val} \cdot \mathrm{Phe}$, Met. OMe, $\mathrm{Val} \cdot \mathrm{OMe}$ and $\mathrm{Phe} \cdot \mathrm{OMe}$ were purchased from Sigma (USA).

\subsection{Protein determination}

Protein concentration was determined using the protein assay reagent kit (BIORAD) according to the manufacturer instructions.

\subsection{SDS-PAGE}

Analysis of the purity of Cardosins A and B was carried out by SDS-PAGE and staining with $\mathrm{AgNO}_{3}$.

\subsection{Enzymatic peptide synthesis}

The condensation reaction was carried out in a biphasic system, consisting of an aqueous phase, containing the enzyme and the $\mathrm{X} \cdot \mathrm{OMe}$ amino acid and an organic phase containing the $\mathrm{CBZ} \cdot \mathrm{Y}$ amino acid as described by Barros et al. [5]. The reaction was conducted at room temperature under magnetic stirring at $100 \mathrm{rpm}$ and sampling at $48 \mathrm{~h}$. Analysis of the reaction product was performed in the aqueous and organic phases. After removal, each phase was

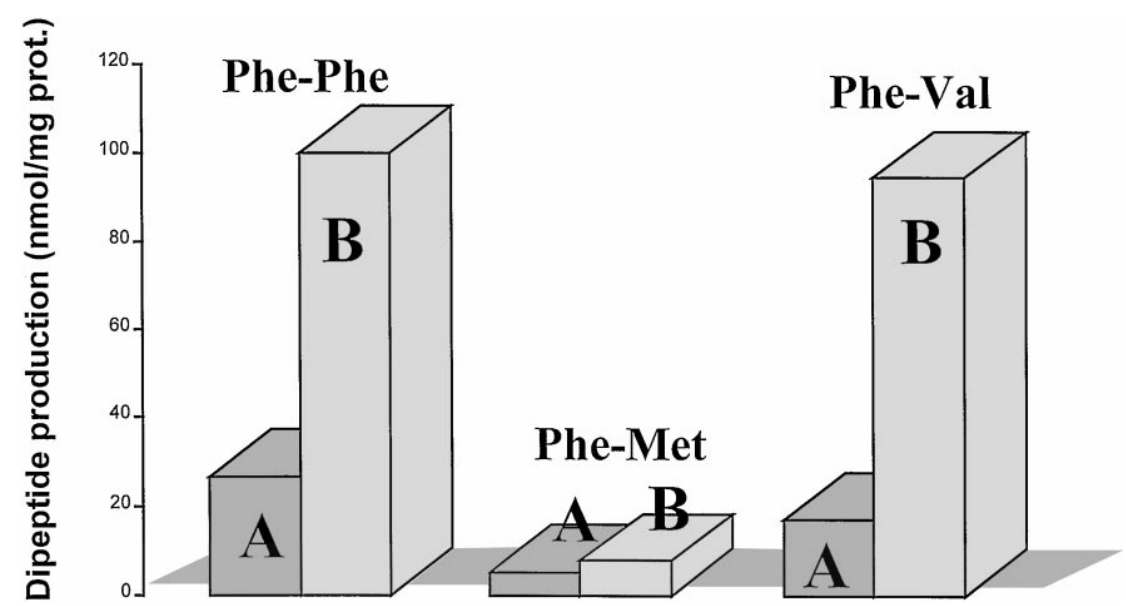

Fig. 1. Production of the dipeptide CBZ $\cdot$ Phe-Phe $\cdot \mathrm{OMe}(\mathrm{Phe}-\mathrm{Phe}), \mathrm{CBZ} \cdot \mathrm{Phe}-\mathrm{Met} \cdot \mathrm{OMe}(\mathrm{Phe}-\mathrm{Met}), \mathrm{CBZ} \cdot \mathrm{Phe}-\mathrm{Val} \cdot \mathrm{OMe}(\mathrm{Phe}-\mathrm{Val})$ by Cardosins A and B over $48 \mathrm{~h}$ of reaction. 


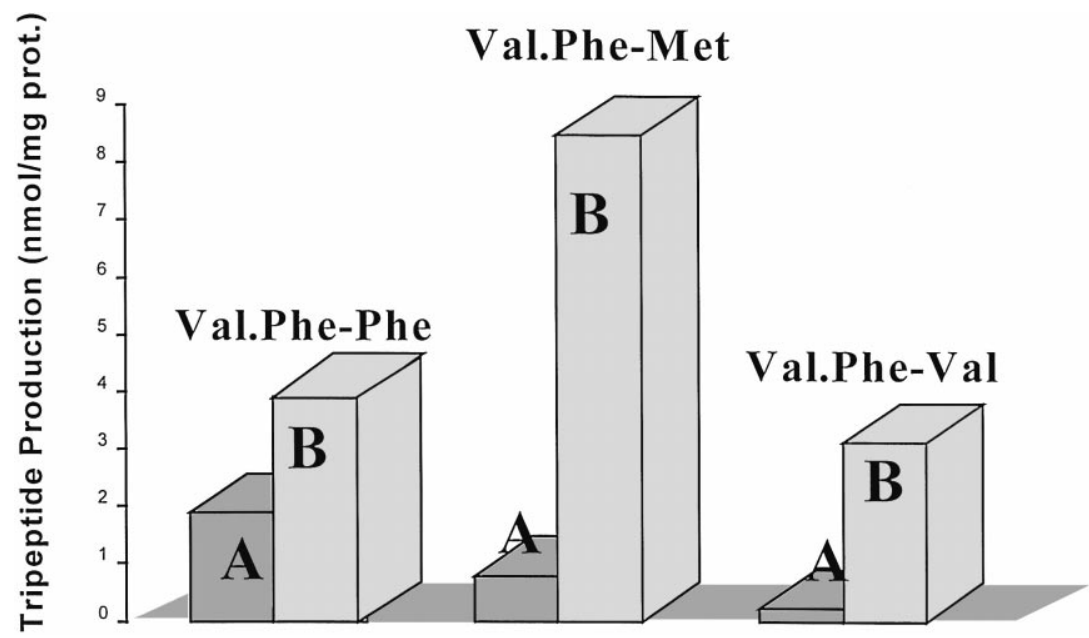

Fig. 2. Production of the tripeptide $\mathrm{CBZ} \cdot \mathrm{Val} \cdot \mathrm{Phe}-\mathrm{Phe} \cdot \mathrm{OMe}(\mathrm{Val} \cdot \mathrm{Phe}-\mathrm{Phe}), \mathrm{CBZ} \cdot \mathrm{Val} \cdot \mathrm{Phe}-\mathrm{Met} \cdot \mathrm{OMe}(\mathrm{Val} \cdot \mathrm{Phe}-\mathrm{Met})$, CBZ $\cdot \mathrm{Val} \cdot$ Phe-Val $\cdot$ OMe (Val $\cdot$ Phe-Val) by Cardosins A and B over $48 \mathrm{~h}$ of reaction.

dried under low pressure and redissolved in ACN $80 \%$, TFA $0.1 \%$ and applied to a HPLC system with a $\mathrm{C} 18$ column (Merck). The column was developed with a linear gradient of ACN $(0-80 \%)$ in $0.1 \%$ TFA pH 2.5 at a flow rate of $0.8 \mathrm{ml} / \mathrm{min}$. The eluate was monitored continuously at $215 \mathrm{~nm}$.

Quantification and identification of the product was performed by amino acid analysis essentially as described by Heinrikson and Meredith [6].

\section{Results and discussion}

The primary specificity of Cardosins A and B was evaluated by condensation of $\mathrm{CBZ} \cdot \mathrm{Phe}$ with $\mathrm{Phe} \cdot \mathrm{OMe}, \mathrm{Val} \cdot \mathrm{OMe}$ and $\mathrm{Met} \cdot \mathrm{OMe}$. Our results show that Cardosins $\mathrm{A}$ and $\mathrm{B}$ have similar order of preference towards $\mathrm{P}^{\prime} 1$ amino acid. While Cardosin A follows Phe $>\mathrm{Val}>\mathrm{Met}$, Cardosin B shows: Phe $\approx \mathrm{Val} \gg \operatorname{Met}$ (Fig. 1). However, the efficiency of Cardosin B in peptide synthesis is higher than Cardosin A.

It seems that the isolated forms of Cardosins present lower relative activities than the one observed for the mixture [7]. Although these are preliminary results, it appears that the final pu- rification step could be avoided, as it brings no advantage in terms of specificity. This probably can be explained by some kind of interaction between both Cardosins that confers them higher stability while together.

The secondary specificity of Cardosins and the effect of Val at $\mathrm{P} 2$ position was also evaluated with the condensation of $\mathrm{CBZ} \cdot \mathrm{Val} \cdot \mathrm{Phe}$ with $\mathrm{Phe} \cdot \mathrm{OMe}, \mathrm{Val} \cdot \mathrm{OMe}$ and $\mathrm{Met} \cdot \mathrm{OMe}$. As can be seen in Fig. 2, the $\mathrm{P}^{\prime} 1$ amino acid preference is modified by the introduction of Val in P2 position. So in the case of Cardosin B, its preference becomes: Met $>$ Phe $>$ Val, while Cardosin A follows: Phe $>$ Met $>$ Val.

On the basis of the results described above and taking into account the stability of Cardosins in organic solvents [8], as well as the simplicity of the purification procedure, these enzymes seem suitable to be considered in future development of enzymatic peptide synthesis process.

\section{References}

[1] A.J. Andersen, J. Fomsgaard, P. Thorbeck, S. Aasmul-Olsen, Chimicaoggi (1991) 18.

[2] J.S. Fruton, Adv. Enzymol. Relat. Areas Mol. Biol. 53 (1982) 239. 
[3] P. Veríssimo, C. Faro, A.J.G. Moir, Y. Lin, J. Tang, E. Pires, Eur. J. Biochem. 235 (1996) 762.

[4] C.J. Faro, A.G.J. Moir, E. Pires, Biotech. Lett. 14 (1992) 841.

[5] M. Barros, C.J. Faro, E. Pires, Biotech. Lett. 15 (1993) 653.

[6] R.L. Heinrikson, S.C. Meredith, Anal. Biochem. 136 (1984) 65.
[7] M. Barros, Síntese de péptidos pela cardosina uma protease aspártica de Cynara sp., Tese de Doutoramento, Coimbra, 1995.

[8] M. Barros, M.G.V. Carvalho, F.A. Garcia, E. Pires, Biotech. Lett. 14 (1992) 174. 